\title{
Secret Life versus Double Life: Modes of Clandestinity of Italian Terrorist Groups
}

\author{
Riccardo Campa \\ Extraordinary Professor, Jagiellonian University \\ Address: Ul. Grodzka 52, Krakow, Poland 31-044 \\ E-mail: riccardo.campa@uj.edu.pl
}

\begin{abstract}
This article presents two distinct modes of operating in a state of clandestinity adopted by Italian leftist terrorist groups, such as the Red Brigades and First Line, in the second half of the 2oth century. The two modes of clandestine life are specified with the terms "invisibility" and "camouflage". The invisibility mode of clandestinity imposes a regime of "secret life" on the group members, while the camouflage mode of clandestinity imposes a "double life" regime on them. The research aims to construct two simplified models, or, to use the Weberian terminology, two "ideal types". Our primary sources are autobiographies published by former terrorists, official propaganda documents and pamphlets compiled by terrorist groups, and court rulings. Our secondary sources are journalist reports and research published by experts in political violence. From the theoretical point of view, the conclusion is, that for law enforcement, it is much more difficult to combat terrorist formations imposing the double life regime on their members rather than a secret life regime. Still, the double life regime is more stressful from a psychological point of view, as it requires an artificial split of personality. In the conclusions, the article expands the discussion to non-Italian terrorist organizations, with a different political or religious agenda.
\end{abstract}

Keywords: sociology of terrorism, Red Brigades, First Line, modes of clandestinity, invisibility, camouflage

\section{Background and Aim of the Research}

As it has often been remarked, there is no generally accepted definition of the term "terrorism" (Malik, 2000; Schmid, 2011; Richards, 2014), even if attempts at determining a consensus definition are not lacking (Weinberg, Pedahzur, Hirsh-Hoefler, 2004; Senechal de la Roche, 2004; Ramsay, 2015). Since the polysemic nature of this term-andconcept is a constant source of misunderstandings and controversies both inside and outside the scientific community, it is advisable to make the meaning one attaches to this word explicit before starting any research on terrorism.

Here, we will start from the much-quoted and sometimes disputed definition proposed by the United States Department of State (2000: viii): “The term 'terrorism' means: premeditated, politically motivated violence perpetrated against noncombatant targets by subnational groups or clandestine agents usually intended to influence an audience". This definition was slightly expanded and better specified by Rex Hudson in research carried out for the United States Congress in 1999, and republished in 2018. Following Hudson (2018), we stipulate that a terrorist act "is the calculated use of unexpected, 
shocking, and unlawful violence against non combatants (including, in addition to civilians, off-duty military and security personnel in peaceful situations) and other symbolic targets perpetrated by a clandestine member(s) of a subnational group or a clandestine agent(s) for the psychological purpose of publicizing a political or religious cause and/or intimidating or coercing a government(s) or civilian population into accepting demands on behalf of the cause".

The keyword on which we will focus is "clandestine". The terrorist act is not perpetrated by soldiers of a national army or by a group of revolutionary guerrillas. These are both military organizations whose combatants wear uniforms and show the enemy their faces. On the contrary, a terrorist act is by definition perpetrated by agents acting in a state of clandestinity. They may be civilian members of a subnational antagonist group, or even military or police officers sent on a mission by a foreign state, but the fact remains that they operate in a state of clandestinity.

In this research, we intend to show that there are at least two distinct modes of operating in such a state of clandestinity. Both methods develop from a primordial state of semi-clandestinity, which generally occurs when the terrorist group is in the process of being gestated. We define the two modes of clandestine life with the terms "invisibility" and "camouflage". The first mode imposes a regime of "secret life", while the second imposes a "double life" regime. To illustrate these two ways of existence, we will proceed by comparing the activities of two Italian terrorist organizations active in the second half of the last century: the Brigate Rosse (the Red Brigades) and Prima Linea (First Line). These are two extreme-left organizations, that is, groups with a very similar Marxist-Leninist political agenda, operating in the same period, and in the same territory. Therefore, the comparison of their modes of organizing clandestinely is particularly instructive. In the conclusions, we will expand the discussion to non-Italian terrorist organizations with a different political or religious agenda.

It goes without saying that here we are just presenting two simplified models, or, to say it in Weberian language, two ideal types (1949: 42). These ideal types should help us to grasp aspects of a social reality that is far more protean and complex than any of its possible representations. Our primary sources are autobiographies written by former terrorists, official propaganda documents and pamphlets compiled by terrorist groups, and court rulings. Our secondary sources are works published by experts in terrorist studies and police reporters.

\section{The Historical Context}

At the end of the 1960s, Italy found itself in a situation of political turbulence. As in other nations of the Western bloc, a student protest broke out in 1968 (Brambilla, 1994; Giachetti, 1998). To this was added, in 1969, a large mobilization of the working class, known as "the warm autumn" (Giachetti, 2013). Millions of workers went on strike and demonstrated to get wage increases and better working conditions. The influence of the Italian Communist Party (PCI) was also growing in the country. Its electoral consensus began to 
approach that of the Christian Democrats (DC), the main government force. The United States showed concern because, amid the Cold War, they could not accept losing control over a crucial outpost in the Mediterranean Sea. The geopolitical role of Italy was crucial because of its proximity to communist Yugoslavia, the Arab-Israeli wars, and countries subjected to the process of decolonization, such as those located in Northern Africa and the Mid-East, which are among the main oil producers in the world.

In the same years, fascist terrorist attacks also took place. Bombs exploded on trains, in buildings, and in squares crowded by protesting students and workers on strike. In particular, the so-called "Piazza Fontana Massacre" took place on December 12th, 1969, in Milan. A bomb exploded inside the Banca Nazionale dell'Agricoltura (National Agrarian Bank), killing 17 people and injuring 88. At the beginning, anarchists were blamed for the horrendous massacre. Afterward, the extreme right-wing militants of a group called Nuovo Ordine (New Order) were indicted, but they would eventually be acquitted.

We still do not know with certainty what happened in those dark years, but the sociologically-relevant fact is that many leftist students, workers, and intellectuals of the time were convinced that the bombing attacks were directed by Italian and American government officers. In their narrative, the neo-fascist groups only supplied the laborers to the subversive conspiracy of the deep state (Soccorso Rosso, 1976; Sanguinetti, 1980; Curcio, 1993; Flamigni, 2004: 17, 41).

Subsequent investigations by the Italian judiciary explored this hypothesis, but no conclusive evidence was found. In 1998, the suspicions of the judiciary had indeed fallen on US officers who supposedly helped the fascists to blow up bombs in order to throw the country into chaos and favor a military coup. The new investigation attracted the attention of the Italian and foreign press (Bellu, 1998; Mastrogiacomo, 2001; Willan, 2000, 2001). According to the judges, the so-called "strategy of tension", based on false flag attacks, was intended to prevent Italy from leaving NATO and the Western bloc. Agents of the Italian secret services were also investigated for "depistaggio" (the misdirection of the judiciary). However, the trial did not lead to any clear conclusion, leaving the perpetrators of the massacre unpunished, with a single exception. As judge Guido Salvini, who was in charge of the investigation, points out, "all the sentences on the Piazza Fontana bombing, even those ended with acquittals, lead to the conclusion that it was an extreme right formation, New Order, to organize the attacks of December 12th". Furthermore, "at least one culprit was found in the final Cassation Court sentence of 2005. $\mathrm{He}$ is Carlo Digilio, the expert in weapons and explosives of the Veneto group of New Order, self-confessed guilty, who provided the explosives for the massacre and who also admitted having been linked to the American secret service" (2013). Quite instructive in this respect is Chapter 56 of the court ruling by the Tribunale Civile e Penale di Milano, entitled "The Involvement of the American Informative Structure in the Strategy of Tension”. Here, judge Salvini specifies that US officers were informed about the extreme right terrorist attacks before and after they happened. However, "according to the intentions of the American structure, the attacks in preparation had only to have a demonstrative scope and not to cause victims" (1998). In other words, false flag attacks were actually on 
the agenda of the US intelligence, but fascist perpetrators went too far by creating many innocent victims and generating an embarrassing situation. One of the hypotheses is that the planned demonstrative attack turned into a massacre due either to an error in the evaluation of the bank's closing time or the malfunctioning of the bomb-timer (Cucchiarelli, 2012). According to this hypothesis, anarchists were involved in the supposedly demonstrative action, although manipulated by fascists and secret services.

Whatever happened, as the Thomas Theorem teaches, "if men define situations as real, they are real in their consequences" (Thomas, 1928: 571).

\section{The Phase of Semi-clandestinity of the Italian Extreme Left}

It is precisely in this context that students and workers sympathizing with the extreme left parties and movements decided to move on, from political propaganda to armed struggle. At the beginning of the 1970s, several terrorist organizations were born that aimed to trigger a socialist revolution in Italy, before the government's conservative bloc would decide to operate a military coup like the one that occurred in Greece on May 4th, 1967, or in Allende's Chile on September 11th, 1973. In this phase, the main organizations are the Gruppi d'Azione Partigiana (Partisan Action Groups), or simply GAP, led by the entrepreneur Giangiacomo Feltrinelli, and the Red Brigades (BR) led by the sociologist Renato Curcio. Later on, many other acronyms will fill newspaper pages (Prette 2006), the most important being NAP, which stands for Nuclei Armati Proletari (Armed Proletarian Nuclei), and PL, which stands for Prima Linea (First Line).

From 1969 to 1972, far-left organizations violated the law, but not in a particularly violent way. This phase has been called "armed propaganda". They carried out low-intensity terrorist actions in order to win the consent and support of the Italian citizenry, especially manual workers. The terrorists set fire to the cars of the managers of large public and private corporations, especially in Milan, Genoa, and Turin (the so-called industrial triangle). They aimed to intimidate managers and to teach them to respect workers in the workplace.

Terrorists go into action after being informed that a worker got "mobbed" (a term that was not popular at the time, but it gives the idea retrospectively) by managers, or died in the workplace due to lack of safety measures. Sometimes, terrorists kidnapped a corporate executive, a trade unionist too compliant with the capitalist methods of exploitation, or a judge who investigated the extreme left militants. The prisoner is tried for the crimes committed against the working class and then released, on the promise of repentance. In general, the abducted "enemies of the people" claim to have been treated "kindly" (Bocca, 1981: 63).

At this stage, terrorists acted in a condition of relative clandestinity or, if one prefers, semi-clandestinity. They visited factories with uncovered faces, they ate in company canteens, and all of the workers knew their names. No one reported them. Company security officers do not intervene, perhaps for fear of retaliation. The terrorists, in addition to being numerous and very resolute, enjoyed external support. Many workers sympathized 
with them because they contributed to making working conditions more bearable. When investigations are started, workers helped terrorists, for instance, by hiding them in their homes. Even some artists and intellectuals sympathized with these subversive groups and financed them.

Some terrorism experts also suspect that terrorist groups were allowed to operate more or less freely by the law enforcement itself, because they contributed to creating an embarrassment to the Italian Communist Party, holding back the electoral rise (Galli, 2005: 7). This strategy has been called "destabilizing to stabilize" (Ibid.: 51). The Communist Party was in difficulty because it was committed to presenting itself as a responsible government force. The communists already governed important Italian cities, provinces, and regions, and aspired to become the government of the nation. The violent and illegal actions of extreme left-wing groups were damaging the PCI's reputation in the eyes of the moderate electorate and potential government allies, such as the Italian Socialist Party or the Christian Democrats.

This intertwining of causes explains the condition of semi-clandestinity, which is described in the memories of the terrorists themselves. For example, in the book $A$ viso aperto (Head-On), Renato Curcio (1993) states: "At the time we were not yet clandestine militants. Everyone in the movement knew us. And in the factory, many, including the PCI trade unionists and the workers who adhered to other extra-parliamentary formations, knew who we were and also what we did. We participated in public debates. We lived in apartments rented with our real names. In short, we acted almost in the open, without much caution. But the Red Brigades were born".

In their autobiographies, Mario Moretti (1994: 16) and Prospero Gallinari (2012: 7879) confirm that the state of clandestinity was preceded by an unclear situation, one in which the police were obviously paying attention to their activities, but the communist militants did not care too much.

The situation of the GAP was very similar. Criminal actions were carried out clandestinely, but it was known that their leader was a leading proponent of armed struggle. Essayist Giorgio Bocca (1981: 23) points out that "Giangiacomo Feltrinelli or Giangi was a billionaire, he belonged to the Milanese upper bourgeoisie". First, he sympathized with the Socialist Party, then with the Communist Party, and finally became infatuated with Fidel Castro and the Cuban revolution, radicalizing his political view. Being a rich and famous entrepreneur, he had no difficulty in publishing his ideas. In 1969, he published a pamphlet entitled Persiste la minaccia di un colpo di stato in Italia! (The Threat of a Coup d'état in Italy Persists!), in which he invited political vanguards to formulate a tactic and a strategy capable of reversing the involution of Italian society. In a second booklet entitled Estate 1969 (Summer 1969), he was even more explicit. Feltrinelli wrote that, because of the repression displayed by authoritarian forces, it is not possible "to change things with the sole use of the weapons of criticism, of democratic conviction", after the definitive decline of revisionism, the hypothesis "that a socialist revolution can be accomplished without the criticism of weapons will disappear". Feltrinelli's sentence echoed 
a famous quote by Karl Marx (1977: 137): “The weapons of criticism obviously cannot replace the criticism of weapons".

In other words, there is no Italian, democratic way to socialism. This was the illusion cradled by the left until 1969. The idea was that the two great parties of the left, the Socialist Party and the Communist Party, once they won an absolute majority in the electoral ballot boxes, could have governed together and changed the country by separating peacefully from the capitalist system and the NATO alliance. This turned out to be an illusion, since in the event of the victory of the left, the reactionary forces, with the support of the United States and Great Britain, would have certainly implemented a military coup in order to keep Italy in the Western camp. According to Feltrinelli, all that remained to the social revolutionary forces was armed struggle.

Feltrinelli fled abroad in 1969 when he discovered to be under investigation for false testimony in favor of two anarchists. Bocca (1981: 31) wrote that "Feltrinelli is an exile who can return to Italy as and when he wants and travel it far and wide since no one is looking for him". One day the painter and his longtime-friend Giuseppe Zigaina saw him arriving at his villa in the city of Grado. Feltrinelli does not want a room. He told his friend that he would sleep in a tent in the garden. He wrote that "Stunned and even a little upset, Zigaina observes Giangi while wearing a Cuban-type military suit and practicing throwing hand grenades in the lawn". However, this is not the only strange episode. Other friends meet Feltrinelli on the train between Rome and Milan "and they don't know how to behave when he pretends not to recognize them and slips away into the corridor, turning his face. He travels across Italy, inspects its GAPs, and pursues the general command of the revolutionary army".

Feltrinelli died in 1972. A bomb he is trying to place on an electricity pylon explodes in his hand. Although it is a surprise for everyone to discover that the well-known entrepreneur was personally involved in sabotage actions, his support for armed struggle and the desire to lead a socialist revolution were certainly not a secret. Once again, a suspicion arises that the Italian Secret Service let Feltrinelli operate, despite being aware of his subversive activities (Galli, 2005: 29). This is why it is appropriate to speak of a semiclandestine mode of existence concerning Feltrinelli's GAP.

\section{Secret Life: The Red Brigades' Mode of Clandestinity}

Feltrinelli's death throws Italian politics into turmoil. The media hype caused by the tragic event pushes the judiciary and the police to act with greater intensity. Large scale counterterrorism operations begin. The GAP, left without a guide and, above all, any funding, is dismantled. Hundreds of communist militants are arrested, others flee abroad, and thousands of citizens are under investigation for aiding subversive activities. The Red Brigades remain in the field. At that point, for them, clandestinity becomes a forced choice. In other words, a crucial decision between two options is to be made; either suspending any subversive activity or starting to operate secretly. Concerning the decision, Curcio (1993) makes it clear that "the idea of going clandestine was not a free choice, but an 
obligatory way to escape the snare that the police held on us. In practice, we became illegal because, otherwise, we were all going to be captured".

How do the Red Brigades implement the clandestine condition? Renato Curcio, Mara Cagol, Alberto Franceschini, and the other militants become invisible. More precisely, they renounce carrying out any legal activity that requires the use of their real identity, rent apartments by using false names, or finance themselves through illegal activities or thanks to donations from sympathizers. This modus operandi, from a technical point of view, has its pros and cons. On the one hand, it offers terrorists greater protection than the previous semi-clandestine condition, so much so that they manage to escape police roundups in factories and leftist political clubs. On the other hand, from a psychological and logistical point of view, the terrorists slip into a dead-end alley. A group operating according to the invisibility mode of clandestinity is subject to strong psychological pressure. Having severed all ties with the ordinary world of study, work, family, affections, friends, and leisure pursuits, etc., the terrorists feel the need to act illegally more frequently. It is this way that they make sense of the difficult, self-imposed regime of a secret life. Giving up everything of importance in human life and then being inactive for a long time is extremely frustrating. By pushing the militants to be more involved in terrorist actions, the condition of invisibility paradoxically exposes them to greater dangers. If for no other reason than the law of probability, the chances of being killed, injured, or arrested increases with the frequency of subversive actions. Furthermore, by reducing or eliminating contacts with people who have an ordinary life, it also increases the likelihood that the terrorists will progressively move away from a realistic reading of the situation in which they operate. They can, for example, overestimate the degree of popular support for their actions, or underestimate the ability of the law enforcement to counter their actions.

Let it be clear that it would be naive to simply think that ordinary people have a correct view of reality, while terrorists live in a fantasy world. We all analyze reality from a limited perspective, from a particular point of view, drawing on certain sources and not others, with the result that our representations of the world are always a mixture of reality and fiction. Only fanatics believe that they have a perfect reading of reality, or that they possess the ultimate truth about everything. However, total isolation, a secret life, and lack of confrontation with people living in different situations can also lead acculturated and intelligent people, as political terrorists generally are, to slip inexorably into a "fanatical" reading of reality. The very idea of feeling invincible, which often haunts terrorists, is itself a result of isolation and invisibility.

Finally, terrorist groups who choose this type of clandestinity may struggle with practical issues, such as finding food, clothes, weapons, and hiding places. Since they do not work, if they do not benefit from substantial funding from rogue states or sympathizers, they are forced to resort to kidnappings for ransom or bank robberies as financing sources. These criminal activities constantly expose them to the danger of being discovered and arrested. 
Even the idea of providing a false identity for renting apartments turned out to be a boomerang. Let us focus on the method adopted by the commander of the anti-terrorist forces, General Carlo Alberto Dalla Chiesa, to vanquish the Red Brigades. We are not referring here to the first arrest of the organization's leaders, which took place on September 8th, 1974, thanks to the infiltration by a secret service collaborator, Silvano Girotto, a former soldier of the Foreign Legion and a Franciscan friar. We refer to the wave of arrests following Curcio's escape from the prison. The definitive knockout occurs thanks to the use of computers. Bocca (1981: 77) describes the operation in the following way: "The carabinieri of general Dalla Chiesa have found the tools to blow up clandestine defenses: one is the study of cadastral maps. They look for the names of those who have bought or rented an apartment in the last two years and then they upload the list into a computer that verifies if they correspond to those of the registry office. Whoever gave a fake name is a suspect, the accommodation must be checked and this is how one gets to some lairs".

After the death of his wife Mara Cagol, who was killed in a shootout with the police in 1975, Curcio hid with Nadia Mantovani in a flat in Milan, at 5 Maderno Street. On January 18th, 1976, "the carabinieri discover the accommodation and take pictures of the tenants from the bell tower in front of Santa Maria da Caravaggio. Among them there is Curcio. After twenty minutes of shooting, the wounded Red Brigades leader surrenders" (86). He will be sentenced to twenty-eight years in prison. He will serve twenty-five, before being released.

\section{Double Life: First Line's Mode of Clandestinity}

First Line was founded in 1976, the year of Curcio's arrest. This terrorist group can, therefore, be seen as an attempt to fill a void in the context of left-wing extremism, even though the Red Brigades also promptly reorganized on new bases under the guidance of Mario Moretti. In more detail, First Line emerged from the failure of Lotta Continua (Enduring Struggle), an extremist but not subversive movement, which still hoped to transform the country through the democratic process. The movement took part in the elections of 1976 but collected only half a million votes, well below the expectations of supporters and leaders (Galli, 2005: 95). At that point, hundreds of militants decided to move on to armed struggle.

Precisely because it emerges from a radical but still legal political movement, First Line exists and operates in a semi-clandestine fashion at the beginning. A member of the organization tells his experience to weekly magazine Panorama as follows: "The sergeants, known to all, could enter the canteen of the Marelli factory and sit at the table of the female clerks, admired as the king's musketeers. In Salò town (end of 1976), as Pietro Villa (one of the founders) remembers, we practically discussed political issues in public". The same militant adds that "in Florence, May 1977, when the national command authority [of First Line] was established, we met in an isolated farmhouse, but in the evening I and the Milanese comrades returned to the city to sleep in a hotel. You can imagine what kind of clandestinity could it be" (Bocca, 1985: 190; Galli, 2005: 100). 
The situation changes when the group begins to operate and raises the bar of subversion by robbing banks and killing political enemies. The new terrorist formation learns a lesson from the recent organizational failure of the Red Brigades. Instead of adopting the invisibility mode of clandestinity, First Line militants choose the camouflage mode of clandestinity. They opt for a double life, instead of a secret life. The old and new Red Brigades, in addition to living in a self-segregation regime, are rigidly organized on a territorial basis. In each city, a column has a monopoly on violent action. Each column is in turn divided into cells. Each operating unit acts in its area of competence. First Line decides to adopt a less rigid scheme. Its squads almost always hit in a different city than the one in which they are based. As mentioned above, clandestinity is also conceived differently: "If for the Red Brigades it means a definitive exit from legality, abandoning the workplace and the family, and entering full-time in the organization, according to First Line, clandestinity means the heavy obligation of a double life" (Bocca, 1981: 111).

It is, anyway, a tough task for the militants. A double-life regime requires a high degree of psychological strength, so much so that this condition is often lived as "a nightmare". As a First Line militant emphasizes, "no one gives up in combat action, because on this ground the psychological strength of each militant is gradually built, moving from the simplest to the most complex actions". On the contrary, "the condition of clandestinity is a nightmare that follows you month after month and year after year" (Ibid.).

Terrorists cannot attend political circles or mix with their comrades of the Movement from which they come. They cannot get drunk, use soft or hard drugs, or lead their lives as other youngsters do. They cannot leave First Line even if they change their mind. Resignation is not an option, except in exceptional cases. Leaving the organization is subject to the opinion of the central committee.

The First Line militant sums up the condition of a double life as follows:

Translated into personal terms, all this means that my public image is that of an exemplary employee. At work, I don't deal with politics and I don't even flex my muscles to defend my union interests. I live with my real name, which is respectable. I keep a clean record. I divide my time between work and family, by dedicating myself to my two children who are two and three years old. Outside the organization, the only person familiar with my political activity is my wife, a communist and revolutionary herself, but external to the organization. I tell her everything related to my activity, but I do not mention the names and facts of the organization. In front of others, I am perfectly camouflaged. (Ibid.: 112)

Even his parents are kept in the dark about his double life regime. However, the First Line militant interviewed by Panorama admits that his mother, maybe because of her "proletarian instinct ... inexplicably suspects something and does nothing but repeat: 'Someday we will see your face printed in the newspapers and then we will cry"' (Ibid.).

The camouflaged militant, to perfectly fit into the role, must, therefore, build a false public identity, at least in terms of personality. One keeps using one's real name and authentic identity card, but must systematically lie. For example, one must publicly support 
political ideas which are exactly the opposite of those actually owned. If one is a communist, one will speak as a conservative, a moderate, or a right-wing supporter so as not to attract suspicion. This is a circumstance that law enforcement should not underestimate. An upside-down identity is a phenomenon not strictly related to crime issues. To take only the best-known examples, in a society intolerant of homosexuality, it is not uncommon for homosexuals to adopt openly homophobic attitudes to remove suspicions from themselves; or, in a society intolerant of non-believers, the atheist sometimes pretends to be a fervent religious person (or vice versa). In short, it would be naive to think of arresting left-wing or right-wing terrorists by chasing kids with a hammer-and-sickle or a swastika on their t-shirt. Terrorists are not silly. If necessary, they will wear a suit and tie and build a respectable public image. The camouflage strategy worked so well that many were shocked to discover that one of the founders and leaders of First Line, Marco Donat-Cattin, was the son of a Minister of the Italian Republic, Carlo Donat-Cattin, a member of the Christian Democrats.

Anyone who indulges in violence in a rather spontaneous way, driven by hatred for someone or something, or like a hooligan, can hardly be a member of the most dangerous and lethal terrorist organizations, as First Line was. These organizations operate secretly, in a cold and calculated manner, at the right time and in the most appropriate way. The militant interviewed by Panorama makes it very clear: "I never feel hatred. In the end, it would mean having a toxic relationship with the tasks to be performed. For me shooting is like being a surgeon in the operating theater: to treat the disease, the scalpel must be used, period. To shoot an exploiter has a dual therapeutic function: that of effectively breaking an articulation of the capitalist command, and the even more important one of showing the workers which is the only approach that can be effective today" (Ibid.).

The second element of the vulnerability of the Red Brigades turned out to be the permeability to the infiltrations of secret agents. To avoid this danger, First Line adopts a very rigid recruitment protocol. Thus, Bocca describes the selection procedure the aspiring militant must undergo:

One of the members of the organization must personally guarantee for the new comrade, and supervise him in a trial period that can last even more than a year. In this period the new militant knows no facts and people of the organization except for two or three comrades of the nucleus to which he belongs. Gradually his operational capacity will be tested in increasingly demanding actions. Only if there are no doubts about his military and political behavior he will be considered a member of the organization. (Ibid.: 116)

If all militants use their real name in ordinary life, they use only pseudonyms inside the clandestine organization. It is exactly the opposite of what happens in the Red Brigades, where false names are given outside, while the militants know each other by their real names.

In addition to not knowing the real names of the comrades, First Line terrorists cannot meet each other outside military actions. From a strictly technical-military point of 
view, this is an excellent organization mode. If a terrorist were captured by the police, even under torture they would not be able to provide the real names, occupations, and places of residence or domicile of other organization members.

It is interesting to note that First Line also carried out common crimes, such as extortions and bank robberies, although the members had a regular income from legal work, and often came from the bourgeoisie (like Donat-Cattin). These illegal activities exposed them to dangers. A lot of money is indeed needed to buy weapons and reward members, but it is not just that. Armed robberies are seen as military-type training. Common crime is a particularly risky activity because it is carried out in competition with other criminal organizations. As confessed by the First Line militant, "the thing that worries us most is not to interfere with organized crime". They have to be careful, because criminals may decide to inform the police about terrorists for two good reasons: (1) to get rid of an annoying competitor; and (2) to gain safe-conduct from the police, as a reward for the political collaboration. Despite all the dangers, "armed robberies and kidnappings continued because the operations of self-financing for a combat group are the basic work, a gray routine that makes everything else possible. And, finally, they are also a good school of guerrilla warfare" (Ibid.: 111). This is the point. Communist militants do not come from the criminal environment. Most of them are students and workers. Therefore, they must learn to handle weapons, to control fear, and to act coolly. When it comes to hitting political adversaries, there is no room for improvisation, just professionalism.

The journalist Giorgio Bocca, after being associated with the Fascist Party in his youth, eventually decided to join the partisan formations during the Second World War. Having direct experience of guerrilla warfare, he noticed similarities between First Line's organizational methods and those of the Italian partisans. He wrote:

It is peculiar how the experiences and phases of the partisan war recur in the terrorist guerrilla war. The "operazioni di accumulo" (accumulation operations), as terrorists call their self-financing activities, equal the "colpi" (blows) of the partisan period, which are the actions aimed at collecting food, money, clothing which also occupied most of their time and men. And again the numerical relationship recurs. Twenty or thirty men of services and information to bring three men to military action.

\section{Conclusions}

The distinct modes of clandestine organization adopted by the two main Italian leftist terrorist formations have been and still are implemented also by terrorist groups of different types. As Hudson (2018) underlines, "the psychology of joining a terrorist group differs depending on the typology of the group. Someone joining an anarchistic or a MarxistLeninist terrorist group would not likely be able to count on any social support, only social opprobrium, whereas someone joining an ethnic separatist group like ETA or the IRA would enjoy considerable social support and even respect within ethnic enclaves". As a consequence, leftist terrorist groups tend to adopt the invisibility mode of clandestinity. 
On the contrary, ethnic separatist groups generally adopt the camouflage mode of clandestinity, precisely because they enjoy the broad support of the surrounding population. They must not necessarily abandon their usual way of life, conceal their real identity, and hide most of the time (unless they have been unmasked and are wanted by the police).

Our study reveals that this general scheme is only partly true. At least during the phase of their activity called "armed propaganda", the Red Brigades could count on the support of a relevant number of intellectuals, students, and workers. This support vanished during the phase called "strike against the heart of the state", as it was much more violent than the previous one. First Line also does not fit perfectly in this general scheme, as the criminal group adopted the organizational mode typical of ethnic separatist groups since the beginning. Anomalous is also the fact that First Line regularly engaged in dangerous criminal activities, such as armed robberies. It is difficult to say if this was strictly necessary. The terrorists assumed that common crime was useful military training. However, those actions could jeopardize their political plans.

Still, the observation and comparison of terrorist organizational strategies lead to a clear theoretical conclusion; it is much more difficult for the police and the judiciary to combat terrorist formations adopting the camouflage mode of clandestinity than the invisibility one. In the former, a member of the organization can take action, place a bomb or assassinate a political opponent, and then return to the shadows, to an ordinary life, to routine legal activities, or by counting on the silence or even the approval of the social environment in which they live. If suspicions are raised against a person, what the police can do is to put the telephones under surveillance, gather information, or start a tracking and observation plan. However, if the suspect remains inactive for months or years, sooner or later the police will have to suspend the scrutiny. Meanwhile, other members of the organization that are not under observation come into action. This is why the activities of nationalist-separatist groups adopting the double life regime can last for decades or even centuries, inherited from parents to children, from generation to generation.

On the contrary, terrorist groups adopting the secret life regime do not last a long time. Two of the main reasons are outlined in this research. Firstly, the law enforcement has at its disposal increasingly sophisticated methods to unmask criminals living under a fake identity and trying to hide in an urban environment. Secondly, invisibility is incompatible with long periods of inaction, due to the high psychological stress generated by a secret-life regime. In turn, the frequency of actions correlates positively with the likelihood of being discovered by law enforcement personnel.

\section{References}

Bellu G. M. (1998) Strage di Piazza Fontana spunta un agente Usa. Nella sentenza-ordinanza del giudice Salvini ricostruita la "Strategia della tensione". La Repubblica, February 11.

Bocca G. (1981) Il terrorismo italiano 1970-1980, Milano: Rizzoli.

Bocca G. (1985) Noi terroristi, Milano: Garzanti. 
Brambilla M. (1994) Dieci anni di illusioni: storia del Sessantotto, Milano: Rizzoli.

Cucchiarelli P. (2012) Il segreto di Piazza Fontana, Firenze: Ponte alle Grazie.

Curcio R. (1993) A viso aperto: Intervista di Mario Scialoja, Milano: Mondadori.

Feltrinelli G. (2012) Estate 1969, Milano: Feltrinelli.

Feltrinelli G. (2012) Persiste la minaccia di un colpo di stato in Italia!, Milano: Feltrinelli.

Flamigni S. (2004) La sfinge delle Brigate Rosse: delitti, segreti e bugie del capo terrorista Mario Moretti, Milano: Kaos Edizioni.

Galli G. (2005) Piombo rosso: la storia completa della lotta armata in Italia dal 1970 a oggi, Milano: Baldini Castoldi Dalai.

Gallinari P. (2012) Un contadino nella metropoli: ricordi di un militante delle Brigate Rosse, Milano: Bompiani.

Giachetti D. (1998) Oltre il Sessantotto: prima durante e dopo il movimento, Pisa: BFS Edizioni.

Giachetti D. (2013) L'autunno caldo, Roma: Ediesse.

Hudson R. (2018) Who Becomes a Terrorist and Why? The Psychology and Sociology of Terrorism, New York: Skyhorse Publishing.

Malik O. (2000) Enough of a Definition of Terrorism, London: Royal Institute of International Affairs.

Marx K. (1977) Critique of Hegel's Philosophy of Right, Cambridge: Cambridge University Press.

Mastrogiacomo D. (2001) Piazza Fontana, matrice estera. La Repubblica, March 21st.

Moretti M. (1994) Brigate Rosse: una storia italiana, Milano: Anabasi.

Prette M. R. (2006) La mappa perduta, Roma: Sensibili alle foglie.

Ramsay G. (2015). Why Terrorism can, but should not be Defined. Critical Studies on Terrorism, vol. 8, no 2, pp. 211-228.

Richards A. (2014) Conceptualizing Terrorism. Studies in Conflict and Terrorism, vol. 37, no 3, pp. 213-236.

Salvini G. (1998) Sentenza - Ordinanza N. 9/92 R.G.P.M. nel Procedimento penale nei confronti di Giancarlo Rognoni ed altri, Tribunale Civile e Penale di Milano - Ufficio Istruzione, sez. 20, February, 3, 1-465.

Salvini G. (2013) La verità su Piazza Fontana. Focus, December 12. Available at: https:// www.focus.it/cultura/storia/la-verita-su-piazza-fontana (accessed 16 June 2021).

Sanguinetti G. (1980) Del terrorismo e dello Stato: la teoria e la pratica del terrorismo per la prima volta divulgate, Milano: Sanguinetti.

Schmid A. P. (2011) The Definition of Terrorism. The Routledge Handbook of Terrorism Research (ed. A. P. Schmid), London: Routledge, pp. 99-157.

Senechal de la Roche, R. (2004). Toward a Scientific Theory of Terrorism. Sociological Theory, vol. 22, no 1, pp. 1-4.

Soccorso Rosso (1976) Brigate Rosse: che cosa hanno fatto, che cosa hanno detto, che cosa se ne è detto, Milano: Feltrinelli.

Thomas W. I., Thomas D. S. (1928) The Child in America: Behavior Problems and Programs, New York: Knopf. 
United States Department of State (2000) Patterns of Global Terrorism, 1999, Washington: United States Department of State.

Weber M. (1949) The Methodology of the Social Sciences, Glencoe: The Free Press.

Weinberg L., Pedahzur A., Hirsch-Hoefler S. (2004) The Challenges of Conceptualizing Terrorism. Terrorism and Political Violence, vol. 16, no 4, pp. 777-794.

Willan P. (2000) Bomb Trial may Call Bush Sr. The Guardian, February 16th.

Willan P. (2001) Terrorists "Helped by CIA" to Stop Rise of Left in Italy. The Guardian, March 26th.

\title{
Тайная жизнь versus двойная жизнь: режимы подпольной деятельности итальянских террористических групп
}

\author{
Риккардо Кампа \\ Экстраординарный профессор, Ягеллонский университет \\ Адрес: Ul. Grodzka 52, Krakow, Poland 31-044 \\ E-mail: riccardo.campa@uj.edu.pl
}

В статье представлены два различных режима секретного действия, принятые итальянскими левыми террористическими группами, такими как «Красные бригады» и «Линия фронта», во второй половине XX века. Два режима подпольной жизни могут быть описаны терминами «невидимость» и «камуфляж». «Невидимый» способ деятельности обязывает членов группы вести «тайную жизнь», а «камуфляжный» накладывает на них обязанность «двойной жизни». Целью исследования является построение двух упрощенных моделей или - используя терминологию Вебера - двух «идеальных типов». Нашими первоисточниками являются автобиографии, опубликованные бывшими террористами, официальные пропагандистские документы и брошюры, созданные террористическими группами, а также судебные постановления. Наши вторичные источники - это газетные репортажи и исследования, опубликованные экспертами в области политического насилия. С теоретической точки зрения, вывод таков, что для правоохранительных органов гораздо сложнее бороться с террористическими группировками, навязывающими своим членам режим двойной жизни, чем с теми, которые ведут режим секретной жизни. Тем не менее, режим двойной жизни является более стрессовым с психологической точки зрения, так как требует искусственного расщепления личности. В заключении статьи представлено расширение дискуссии на неитальянские террористические организации с другой политической или религиозной повесткой дня.

Ключевые слова: социология терроризма, Красные бригады, Первая линия, режимы подпольной деятельности, невидимость, камуфляж 